Research Paper

\title{
Sex chromosome abnormalities and psychiatric diseases
}

\author{
Xinzhu Zhang ${ }^{1}$, Jian Yang ${ }^{2}$, Yuhong $\mathrm{Li}^{1,2}$, Xin $\mathrm{Ma}^{1,2}$ and $\operatorname{Rena}^{\mathrm{Li}^{1,2,3}}$ \\ ${ }^{1}$ Beijing Institute for Brain Disorders, Capital Medical University, Beijing, China \\ 2 Beijing Key Laboratory of Mental Disorders, Beijing Anding Hospital, Beijing, China \\ ${ }^{3}$ Center for Hormone Advanced Science and Education, Roskamp Institute, Sarasota, FL, USA \\ Correspondence to: Rena Li, email: rli@rfdn.org \\ Keywords: schizophrenia, autism, ADHD, depression, gender
}

Received: October 12, $2016 \quad$ Accepted: December 07, $2016 \quad$ Published: December 15, 2016

\section{ABSTRACT}

\begin{abstract}
Excesses of sex chromosome abnormalities in patients with psychiatric diseases have recently been observed. It remains unclear whether sex chromosome abnormalities are related to sex differences in some psychiatric diseases. While studies showed evidence of susceptibility loci over many sex chromosomal regions related to various mental diseases, others demonstrated that the sex chromosome aneuploidies may be the key to exploring the pathogenesis of psychiatric disease. In this review, we will outline the current evidence on the interaction of sex chromosome abnormalities with schizophrenia, autism, ADHD and mood disorders.
\end{abstract}

\section{INTRODUCTION}

Sex chromosome abnormalities are the most common chromosomal abnormalities in humans [1]. Sex chromosome aneuploidies can influence neurodevelopment and often result in more difficulties in inhibition, mental flexibility, sustained attention, working memory, verbal skills and executive function impairment [2], while some of these symptoms partly overlap with psychosis. Studies have demonstrated that genes in the sex chromosome may influence psychiatric disease by altering the basic differentiation process of the neurons [3], encoding proteins [4], synaptic transmission [5] and so on. For example, X-linked genes have specific impacts on the development of the amygdala and its connections with cortical centers involved in social-cognition processing as shown in Figure 1 [6], while structural abnormalities of the amygdala in individuals have been proven to increase risk for schizophrenia [7]. Therefore, the study of sex chromosomes in psychiatric diseases may provide a new angle to understand the sex differences in the pathogeneses of psychiatric diseases. In this review, we gathered discoveries in psychiatric research and discussed the relationship between sex chromosomes and psychosis in order to provide some useful insights on sex-specific genetic mechanisms for psychiatric disease.

\section{GENES IN SEX CHROMOSOMES AND PSYCHIATRIC DISEASES}

An important category of genetic linkage with sex chromosomes is that the genes on $\mathrm{X}$ or $\mathrm{Y}$ chromosomes not only determine male and female traits but also carry many sex related characteristics. While men are the only ones who inherit $\mathrm{Y}$ chromosomes and Y-linked traits, both men and women can get X-linked genes since both inherit X chromosomes. There are 1,098 known human $\mathrm{X}$-linked genes and only about 26 known genes located in the $\mathrm{Y}$ chromosome. Some X or Y chromosome genes have been identified as candidate genes for psychiatric disease, such as schizophrenia (SCZ), major depression disorder (MDD), bipolar disorder (BPD), attentiondeficit hyperactivity disorder (ADHD), autism spectrum disorder (ASD). In this session, we will highlight some genes located on $\mathrm{X}$ or $\mathrm{Y}$ chromosomes and summarize their linkage with these psychiatric disorders. As shown in Figure 1, we will review each of the genes and their connection to specific psychiatric diseases.

The human opposite paired-containing gene $(H O P A)$ in SCZ

HOPA is an $\mathrm{X}$-chromosome gene that codes for a critical family of proteins regulating transcription via the nuclear receptor. Accumulating studies of HOPA exonic polymorphisms in SCZ patients suggested that $H O P A^{12 b p}$, 
an exonic polymorphism, plays critical roles in neuronal growth and differentiation and is associated with increased risk for $\mathrm{SCZ}$, concluding that the $H O P A^{12 b p}$ allele is a risk factor for SCZ in subjects of European ancestry [811]. Furthermore, a study reported that $H O P A^{12 b p}$ allele is associated with the negative symptoms of SCZ by comparing the positive and negative symptoms in 43 male $H O P A^{12 b p} \mathrm{SCZ}$ patients and 137 HOPA wild controls [11]. However, a study of $99 \mathrm{SCZ}$ patients (56 males, 43 females) in the Chinese population reported no association of HOPA with SCZ [12]. Although the association between HOPA polymorphisms and SCZ in different populations remains unclear, another study of $367 \mathrm{SCZ}$ patients and 178 BPD patients from Bulgaria and UK showed little to no correlation between $H O P A^{12 b p}$ and SCZ and BPD [13]. Controversial findings hypothesized that mutations may not occur directly on $H O P A^{12 b p}$, but in other genes in the $\mathrm{Xq} 13$ region, especially those that have neurobiological function. For example, the human neuroligin-3 gene is the closest to the HOPA gene. Neuroglin gene's putative promoter region overlaps the last exon of the $H O P A$ gene located less than $900 \mathrm{bp}$ from the position of the $H O P A^{12 b p}$ [14].

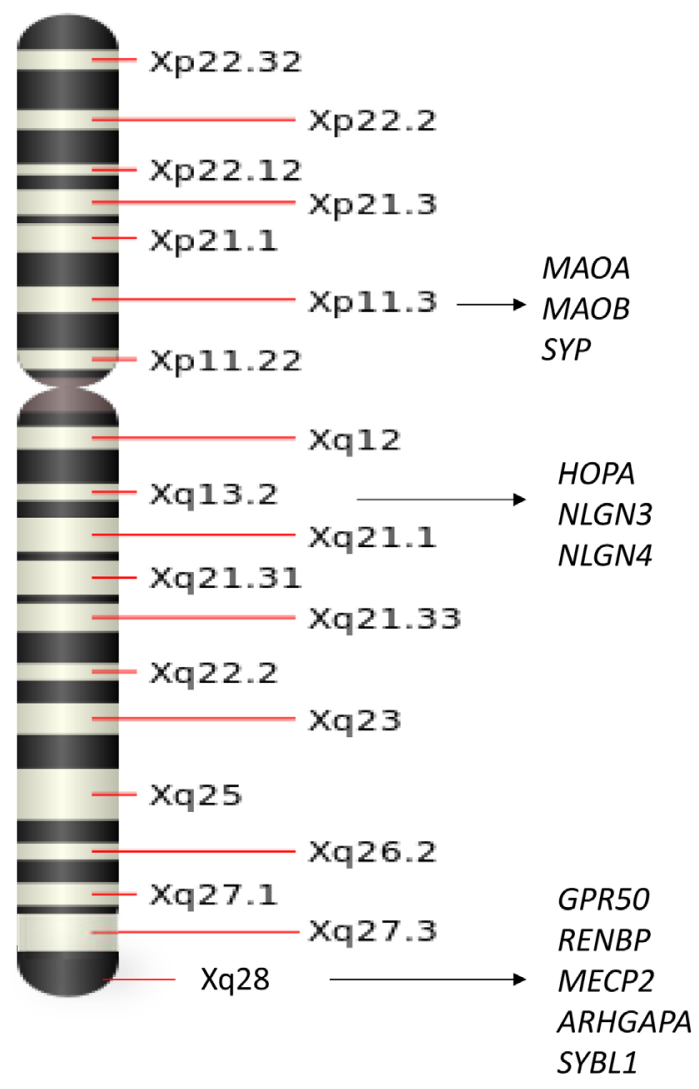

\section{G-protein-coupled receptor 50 (GPR50) in mood disorders and SCZ}

GPR50 is located in X chromosome $\mathrm{Xq} 28$ and has been studied as a candidate gene for BPD, MDD and SCZ. A good example is a case-control study of subjects with BPD $(n=264)$, MDD $(n=226)$ and SCZ $(n=263)$ with ethnically matched controls $(n=562)$. The study discovered an association between an insertion/deletion polymorphism in exon 2 of GPR50 and BPD and MDD, while other single-nucleotide polymorphisms (SNPs) within GPR50 showed associations between MDD and $\mathrm{SCZ}$. However, all of the associations were found only in females, suggesting a sex-specific risk of GPR50 for BPD, MDD and SCZ[15]. A similar sex-specific risk of GPR50 in other psychiatric disorders has been reported by other independent studies. For instance, by genotyping 400 men and 610 women who had depression for more than 12 years, studies found a female-specific association between GPR50 variants and later-life depression (specific for depression combined with anxiety), and female patients showed more inclination for currently having depression or anxiety than male patients [4]. Furthermore, a study of 106 seasonal affective disorder patients ( 80 females and 26 males) found that female patients with BPD (36\%)

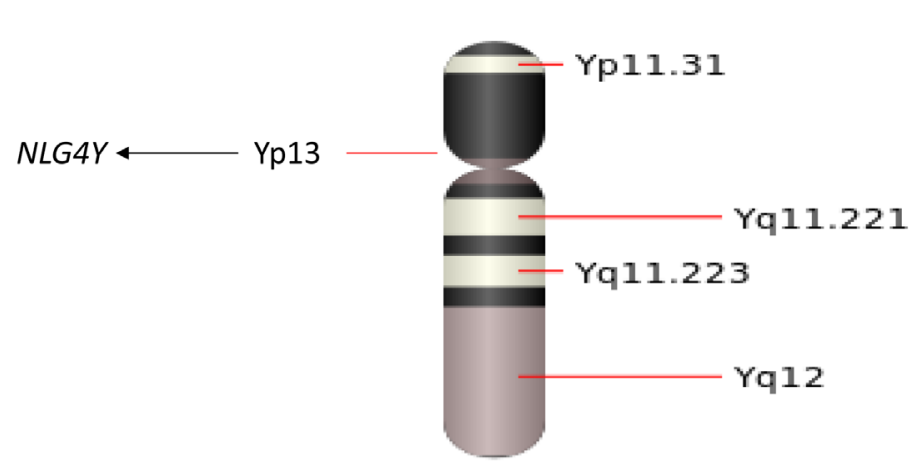

Figure 1: A schematic of the sex chromosomes with several adjacent genes that have been associated with psychiatric diseases. 
Table 1: List of X- or Y-genes about the psychosis disorder

\begin{tabular}{|c|c|c|c|c|}
\hline Gene & Diagnosis & Subject & Comments & Year \\
\hline \multirow[t]{6}{*}{$H O P A(\mathrm{Xq} 13)$} & $\mathrm{SCZ}$ & $\begin{array}{l}\text { Female SCZ }(\mathrm{n}=50) \text {, mothers of male } \mathrm{SCZ} \\
(\mathrm{n}=50)\end{array}$ & $\begin{array}{l}\text { Disease related variants: Prom 1, Exon 6b, Exon 15, } \\
\text { Exon } 23 \text { b, Exon 28, Exon } 43\end{array}$ & $2003[8]$ \\
\hline & $\mathrm{SCZ}$ & 569 SCZ (378 males, 191 females) & $\begin{array}{l}11 \text { male patients and } 11 \text { female patients have the } \\
H O P A^{12 b p} \text {. }\end{array}$ & $2007[9]$ \\
\hline & $\mathrm{SCZ}$ & $\begin{array}{l}\text { 172 SCZ (128 males, } 45 \text { females); controls } \\
\text { (1035 males, } 471 \text { females) }\end{array}$ & $\begin{array}{l}\text { HOPA mutation rates are } 4 \% \text { male SCZ, } 6 \% \text { female } \\
\text { SCZ, } 1 \% \text { male controls and } 1.2 \% \text { female controls. }\end{array}$ & $2001[10]$ \\
\hline & $\mathrm{SCZ}$ & 180 male SCZ (43 HOPA ${ }^{12 b \mathrm{p}}, 137$ HOPA $\left.^{\text {wild }}\right)$ & $\begin{array}{l}\text { HOPA genotypes are related with bizarre behavior, not } \\
\text { with positive symptoms. }\end{array}$ & $2004[11]$ \\
\hline & SCZ & 99 SCZ (56 males, 43 females) & No association in HOPA mutations and SCZ. & $2003[12]$ \\
\hline & $\begin{array}{l}\mathrm{SCZ} \\
\mathrm{BPD}\end{array}$ & $\begin{array}{l}367 \text { SCZ (265 males, } 102 \text { females) and } 368 \\
\text { controls (258 males and } 110 \text { females); } 178 \\
\text { BPD ( } 81 \text { males and } 97 \text { females) and } 188 \\
\text { controls ( } 84 \text { males and } 104 \text { females) } \\
\end{array}$ & $\begin{array}{l}\text { The risk of } H O P A^{12 b p} \text { were found higher in the SCZ and } \\
\text { BPD than normal controls. }\end{array}$ & $2003[13]$ \\
\hline \multirow[t]{3}{*}{$\begin{array}{l}\text { GPR50 } \\
(\mathrm{Xq} 28) \\
\end{array}$} & MDD & $\begin{array}{l}\text { Elderly MDD with } 12 \text { years' depression } \\
\text { incident ( } 400 \text { males, } 610 \text { females) }\end{array}$ & $\begin{array}{l}\text { rs13440581, rs2072621, rs561077 are only significantly } \\
\text { associated with females, not in males. }\end{array}$ & $2015[4]$ \\
\hline & SAD & $106 \mathrm{SAD}$ (80 females and 26 males) & $\begin{array}{l}\text { rs2072621 SNP is significantly associated with SAD in } \\
\text { females, but not in males. }\end{array}$ & $2012[16]$ \\
\hline & $\begin{array}{l}\text { BPD } \\
\text { SCZ } \\
\text { MDD }\end{array}$ & $\begin{array}{l}264 \text { BPD (121 males, } 143 \text { females), } 263 \\
\text { SCZ (187 males, } 76 \text { females), } 226 \text { MDD } \\
\text { (90 males, } 136 \text { females) }\end{array}$ & $\begin{array}{l}G P R 50^{w t / D 502-505} \text { polymorphism is both significantly } \\
\text { associated with BPD and MDD in females. }\end{array}$ & $2005[15]$ \\
\hline \multirow[t]{3}{*}{$\begin{array}{l}\text { NLGN3 } \\
(\mathrm{Xq} 13.1) \\
N L G N 4 X \\
(\mathrm{Xp} 22.31) \\
\end{array}$} & ASD & $\begin{array}{l}40 \text { ASD ( } 36 \text { males, } 4 \text { females) and } 150 \\
\text { controls ( } 89 \text { males } 61 \text { females) }\end{array}$ & $\begin{array}{l}\text { One SNP in } N L G N 3 \text { rs17857401; eight SNPs in } \\
\text { NLGN4X: rs111953947, rs72413786, rs2290487, } \\
\text { rs2290488, rs7049300, rs3747333, rs3747334, } \\
\text { c.1597A }>\text { G (p.K378R). }\end{array}$ & $2013[18]$ \\
\hline & ASD & 158 ASD (140 males and 18 females) & $\begin{array}{l}\text { p.R451C in NLGN3 (Xq13 locus, OMIM 300336) and } \\
\text { c.1186insT in NLGN4X (Xp22.3 locus, OMIM 300427). }\end{array}$ & $2003[17]$ \\
\hline & ASD & 107 ASD (102 males, 5 females) & $\begin{array}{l}\text { SNPs in NGLN4X: rs2290488, rs7049300, rs3747333, } \\
\text { rs3747334, and one novel synonymous variant (A558). }\end{array}$ & $2008[19]$ \\
\hline \multirow[t]{4}{*}{\begin{tabular}{|l|}
$M A O A$ \\
$(\mathrm{Xp} 11.3)$ \\
\end{tabular}} & $\mathrm{SCZ}$ & $346 \mathrm{SCZ}$ & $\begin{array}{l}\text { No allelic association between } M A O A \text { and aggressive } \\
\text { behavior measured by total OAS or OAS4. }\end{array}$ & $2004[25]$ \\
\hline & ADHD & $\begin{array}{l}1462 \text { ADHD ( } 1216 \text { males and } 246 \text { females) } \\
\text { and } 807 \text { controls (507 males, } 300 \text { females) }\end{array}$ & $\begin{array}{l}\text { SNP in MAOA rs5905859 and in SYP rs5906754 are } \\
\text { highly associated with ADHD compared to controls. }\end{array}$ & $2014[3]$ \\
\hline & ADHD & $\begin{array}{l}456 \text { ADHA children (379 males, } 77 \\
\text { females) and } 108 \text { normal controls ( } 77 \\
\text { males, } 31 \text { females) }\end{array}$ & $\begin{array}{l}\text { SNPs in MAOA: rs3788862, rs5905859, rs3027400, } \\
\text { rs2239448, rs1137070. }\end{array}$ & $2015[21]$ \\
\hline & MDD & $\begin{array}{l}146 \text { MDD ( } 44 \text { males, } 102 \text { females) and } 101 \\
\text { controls ( } 33 \text { males and } 68 \text { females) }\end{array}$ & $\begin{array}{l}\text { Higher activity of the MAOA gene promoter alleles is } \\
\text { associated with MDD in females. }\end{array}$ & $2000[22]$ \\
\hline \multirow[t]{3}{*}{\begin{tabular}{|l|}
$M A O B$ \\
$(\mathrm{Xp} 11.3)$ \\
\end{tabular}} & ASD SCZ & $\begin{array}{l}142 \text { ASD (122 males, } 20 \text { females); } 143 \mathrm{SCZ} \\
\text { (95 males, } 48 \text { females) }\end{array}$ & $\begin{array}{l}\text { MAOB gene various } \mathrm{p} . \mathrm{R} 448 \mathrm{X} \text { is associated with } \mathrm{SCZ}, \\
\text { not to ASD. }\end{array}$ & $2011[24]$ \\
\hline & $\mathrm{SCZ}$ & $\begin{array}{l}90 \text { family subjects with two or more } \\
\text { members with SCZ }\end{array}$ & $\begin{array}{l}\text { the PAH } 232 \text { bp and the GABRB3 } 191 \text { bp allele in } \\
M A O B \text { are significantly association with the delusions } \\
\text { factor and the hallucinations factor detected by } \\
\text { QPDTPHASE, respectively. }\end{array}$ & $2009[78]$ \\
\hline & ADHD & $\begin{array}{l}150 \text { ADHD probands }(126 \text { males, } 24 \\
\text { females }), 150 \text { controls }(125 \text { males, } 25 \\
\text { females })\end{array}$ & $\begin{array}{l}\text { Two of } 7 \text { functional variants were found to be } \\
\text { polymorphic (rs2283728 'C', rs3027440 'T') alleles and } \\
\text { associated with ADHD probands. }\end{array}$ & $2016[23]$ \\
\hline \multirow[t]{3}{*}{$\begin{array}{l}M E C P 2 \\
(\mathrm{Xq} 28)\end{array}$} & $\mathrm{SCZ}$ & $\begin{array}{l}498 \mathrm{SCZ} \text { and } 2071 \text { controls for GWAS; } \\
1027 \mathrm{SCZ}, 1001 \text { controls, } 71 \text { affected } \\
\text { offspring and } 173 \text { unaffected family } \\
\text { members for follow up study }\end{array}$ & $\begin{array}{l}\text { GWAS show } 10 \text { top candidate genes and } 3 \text { of the } 10 \\
\text { genes were located within the Xq28 region (RENBP, } \\
\text { ARHGAP4, MECP2). In follow up study, } 4 \text { SNPs were } \\
\text { found in SCZ: rs2269372 in RENBP, rs2269368 in } \\
\text { ARHGAP4, rs2734647 and rs2239464 in MECP2. } \\
\end{array}$ & $2014[27]$ \\
\hline & ASD & 69 females clinically diagnosed with ASD & $\begin{array}{l}\text { One ASD carries a heterozygous } 41-b p \text { deletion at } \\
\text { nucleotides } 1157-1197 \text { of MECP2, and another ASD } \\
\text { carries a single nucleotide sequence change } 880 \text { C3T. }\end{array}$ & $2003[28]$ \\
\hline & ASD & 59 ASD (42 males and 17 females) & No mutation in $M E C P 2$ gene coding region in ASD. & 2001[29] \\
\hline \multirow[t]{2}{*}{$\begin{array}{l}\text { SYBL1 } \\
(\mathrm{Xq} 28)\end{array}$} & BPD & $110 \mathrm{BPD}$ and 119 controls & $\begin{array}{l}\text { four single nucleotide polymorphisms were detected } \\
\text { in BPD and only frequency of C allele showed a trend } \\
\text { toward to BPD in males. }\end{array}$ & $2000[30]$ \\
\hline & BPD & $\begin{array}{l}164 \text { BPD ( } 67 \text { males, } 97 \text { females), and } 267 \\
\text { controls ( } 165 \text { males, } 102 \text { females) }\end{array}$ & $\begin{array}{l}\text { The } \mathrm{C} \text { allele showed be more frequent in males with } \\
\text { BPD than in respective controls. }\end{array}$ & $2002[31]$ \\
\hline $\begin{array}{l}N L G N 4 Y(\mathrm{Yq} \\
11.22)\end{array}$ & ASD & 26 boys (XYY) and 11 males control (XY) & $\begin{array}{l}\text { NLGN4Y correlated with } \mathrm{XYY} \text { in the autistic } \\
\text { mannerisms symptom t-scores. }\end{array}$ & $2015[32]$ \\
\hline
\end{tabular}

Notable: $\mathrm{SCZ}=$ Schizophrenia BPD= Bipolar Disorder SAD=Seasonal Affective Disorder MDD= Major Depressive Disorder $\mathrm{ADHD}=$ Attention Deficit Hyperactivity Disorder ASD $=$ Autism Spectrum Disorder 
or MDD (60\%) are related to GPR50 variants. The sexspecific association between the variant of GPR50 and mood disorders in females suggest that GPR50 may be a female-specific risk for mood disorder [16]. A recent large cohort study of GPR50 polymorphisms in 1010 elderly men and women showed that women with heterozygous for rs13440581 showed an increased risk of depression and the risk increased when depression was combined with anxiety in women homozygous for rs2072621. Another GPR50 polymorphism rs561077 was also associated with an increased risk of incident depression specifically. However, no significant associations were observed in men [4]. Together, studies of GPR50 support that GPR50 may contribute to a female-specific risk for SCZ, BPD, and MDD.

\section{Neuroligin 3 gene (NLGN3), neuroligin $4 \mathrm{X}$ gene $(N L G N 4 X)$ in ASD}

NLGN3 and NLGN4X are the X-linked genes located in Xq13.1 and Xp22.31, respectively. Studies found an association between $N L G N 3, N L G N 4 X$ and ASD. By screening for NLGN3 and NLGN4X mutations in subjects with ASD or Asperger syndrome (a type of ASD with higher cognitive ability and normal language), one study of 140 males and 18 females identified two affected brothers; one has ASD and another has Asperger syndrome in one Swedish family. The two affected brothers shared the same frameshift mutation in NLGN4X with their mother while no mutations were found in other family members. In addition, a similar genetic phenomenon of $N L G N 3$ was found in another Swedish family in two brothers with ASD and Asperger syndrome, respectively. There is a $\mathrm{C}$ to $\mathrm{T}$ transition (changing arginine residue into cysteine) in NLGN3 found in the two affected brothers, while the same mutation was also found in their mother, but not in other family members [17]. Furthermore, studies screened the full length of the coding regions of the NLGN3 and NLGN4X genes in ASD patients and their parents, including nine nucleotides on $N L G N 3$ and $N L G N 4 X$ gene to be associated ASD as indicated in Table 1. One study of 40 Greek autism patients and their parents found the c. - $705 \mathrm{~A}>\mathrm{G}$ nucleotide change located in the $N L G N 4 X$, exon 1 of variant 1 in the father of a young girl who has ASD and the mother of a young boy who suffers ASD. In addition, the same study also found a 4-yearold boy with severe ASD inherited c. - $206 \mathrm{G}>\mathrm{C}$, is located in $N L G N 4 X$ exon 2 from his healthy mother [18]. However, an independent study of 107 autism patients (102 males, 5 females) found no genetic variants for both X-linked genes $N L G N 3$ and $N L G N 4 X$ in ASD on a high functioning level by screening four polymorphisms and one novel synonymous variant [19]. A most recent study reported that in addition to point mutations were identified in $N L G N 4 X$ and $N L G N 3$ in patients with ASD, an elevated $N L G N 4 X$ phosphorylation is also interplayed with the genetic mutation into the synaptic dysfunction of ASDs [20]. Together, data suggested that mutations on NLGN3 and NLGN4X might increase the risk of autism while polymorphisms of different nucleotides in autism still need further investigation.

\section{Monoamine oxidase A or B (MAOA or $M A O B)$ in ADHD, ASD, SCZ and depression}

$M A O A$ is a candidate gene located in $\mathrm{Xp} 11.3$ for various psychiatric disorders. For example, studies showed that the MAOA is associated with ADHD by Pedigree-based generalized multifactor dimensionality reduction (PGMDR) on 1462 ADHD children and 807 unaffected controls, [3] while another study found that $M A O A$ variants may be associated with sustained attention deficit by genotyping DNA from ADHD children ( $n$ $=242$ ) which evaluated the attention deficit by a digit cancellation test [21]. Interestingly enough, $M A O A$ is also related to depression in female patients. Studies of $M A O A$ genotypes (type 1 with at least one short allele 3 , type 2 with only the long alleles $3.5,4$ or 5 ) in depressive patients and controls found that females with major depression had significantly higher frequencies of $M A O A$ type 2 than that in female healthy controls, while no differences were found in $M A O A$ type 1 between depression patients and controls regardless of genders [22]. In addition to $M A O A$, $M A O B$ is also association with ADHD. A new study of 150 subjects with ADHD (126 males, 25 females) found higher frequencies of seven functional variants in $M A O B$ (Table 1 ) in ADHD patients compared to controls (125 males and 25 females) [23]. $M A O B$ is also thought to be one of the best candidate genes for ASD and SCZ by sequencing 113 candidate genes from 142 ASD patients and $143 \mathrm{SCZ}$ patients [24]. However, the associations between $M A O A$ or $M A O B$ and SCZ have been challenged by several independent studies. A study analyzed $346 \mathrm{SCZ}$ patients by the Overt Aggression Scale (OAS) found no support of the two genes as risk factors for positive symptoms such as aggressive behavior [25]. Another study found that $M A O B$ is related with the etiology of psychotic diseases, but not specifically for SCZ while the authors failed to prove the association between $M A O B$ and five psychotic disorder features, such as delusions, hallucinations, mania, depression, and negative symptoms [26].

\section{Methyl CpG binding protein 2 (MECP2) in SCZ and ASD}

MECP2, a gene located on $\mathrm{Xq} 28$ was identified in SCZ patients by a genome-wide association study (GWAS) on $498 \mathrm{SCZ}$ patients and 2015 controls [27]. While the association between $M E C P 2$ and ASD is still not clear, a recent study identified mutations in $M E C P 2$ in two of 
the 69 female ASD patients, suggesting female-specific association between MECP2 and ASD [28]. However, other study found no mutations or polymorphisms in the MECP2 gene among 59 autism patients (42 males and 19 females) [29]. Therefore, whether $M E C P 2$ is a $\mathrm{x}$-chromosome related risk gene for autism remains further confirmation.

\section{Synaptobrevin-like 1 (SYBL1) in BPD}

SYBL1 is located on $\mathrm{Xq} 28$ maps to the $\mathrm{Xq}$ pseudoautosomal region and is a candidate gene for BPD. A study of 110 BPD patients (53 males and 57 females) and 119 control subjects (65 males and 54 females) by single-strand conformation polymorphism(SSCP) analysis and DNA sequencing found an increase in the frequency of SYBL1 in males but not in female BPD patients [30]. As shown in Table 1, the sex-specific risk of SYBL1 for BPD has been also supported by other studies. For instance, a study observed a significantly increased frequency of genotypes homozygous for the $\mathrm{C}$ allele, a novel polymorphism found on SYBL1, in males with BPD in comparison with male controls [31].

Moreover, several other X-linked genes were also observed as potentially relevant variants in ASD and SCZ (for example IL1RAPL1, OPHN1, TM4SF2/TSPAN7, or $M E C P 2)^{5}$ as listed in Table 1.

\section{Neuroligin 4 Y (NLGN4Y) in ASD}

Compared to the $\mathrm{X}$ chromosome, the $\mathrm{Y}$ chromosome is relatively understudied. $N L G N 4 Y$ is located in Yp13 and is related to autism. A study of 26 boys with an extra copy of the Y chromosome (XYY) diagnosed with autism scales had the expression two-fold higher level of NLGN4Y than that in normal controls [32]. There are other Y-linked genes like SPR and STS which are expressed in the brain and influence sex-related brain structure [33], but no evidence of a relationship between these genes and psychiatric disease. Due to the limited psychiatric diseaserelated proteins were encoded by the Y-chromosome, the potential impact of Y-linked genes on psychiatric disease has been less investigated [34].

\section{SEX CHROMOSOME ABNORMALITIES IN PSYCHIATRIC DISEASES}

Sex chromosome abnormalities include chromosome inactivity impairment, $\mathrm{X}$ chromosome escaping, additional copies of sex chromosomes (aneuploidies) and more. We will discuss the sex chromosome abnormalities in several major psychiatric disorders in this section.

\section{Schizophrenia (SCZ)}

The loss or gain function of $\mathrm{X}$ chromosome in SCZ has been reported. For example, one study looked at mosaic X chromosome aneuploidies in $21 \mathrm{SCZ}$ patients who had first-degree relatives with psychosis conditions and their healthy relatives, and found one SCZ patient who had X chromosome aneuploidy with $46 X X / 47 X X X / 48 X X X X$ while her healthy mother carried $46 \mathrm{XX} / 45 \mathrm{X}$ [35]. This data suggested that $\mathrm{X}$ chromosome aneuploidies might contribute more risk for familial SCZ. The high frequency of X aneuploidy among patients with SCZ has also been reported by other studies using structured diagnostic criteria and karyotypic laboratory analyses. In one meta analysis paper, using 34910 consecutive newborns as healthy controls, studies found that extra copies of $\mathrm{X}$ chromosomes, such as the frequency of $47 \mathrm{XXY}$ and $47 \mathrm{XXX}$ have a 4-6 times greater risk in SCZ patients compared to the sex chromosome aneuploidies in newborn controls [36]. The same paper also found a higher rate of XXX genotypes in female patients with SCZ. Interestingly, an individual with a missing $\mathrm{X}$ chromosome copy, such as $\mathrm{XO}$ was also reported in female SCZ patients (1 XO out of 11 SCZ patients) [37]. Furthermore, studies also reported that female SCZ patients carry XO karyotype (11/6483) three times more frequent than that in the general female population $(9 / 17,038)[36,38]$, which is consistent with some case reports showing XO karyotype in female SCZ patients [39, 40]. However, there are different results in terms of sex chromosome aneuploidies reported by studies with large clinical sample size. For instance, study found no association between the aneuploidies of $\mathrm{X}$ or Y chromosomes and risk of SCZ in 33512 persons who registered in The Danish Cytogenetic Central Register (DCCR) [37]. Among the 33512 individuals, there are 1122 cases with sex chromosome abnormally, including $18(1.6 \%)$ SCZ patients (13 with 47XXY and 5 with $47 \mathrm{XYY})$. The frequency of SCZ in $47 \mathrm{XXY}(72 \%)$ is higher than the risk of SCZ in general population(1\%) [41]. Since it is known that sex chromosome aneuploidy increases with age in peripheral lymphocyte cultures [42], a study of longitudinal X chromosome aneuploidy can be done in peripheral samples. For instance, a study of SCZ patients and sex- and age-matched controls (age from 12 to 77 years) found that the incident of missing $\mathrm{X}$ chromosomes was found only in females. However, the frequency of $\mathrm{X}$ chromosome loss was significantly higher in female SCZ than in normal females $(\mathrm{p}<0.001)$ only in the 40- to 49-years-old age group. No significant differences of $X$ chromosome loss were found in other age groups between $\mathrm{SCZ}$ and controls. One noteworthy thing is that the $\mathrm{X}$ chromosome alterations in SCZ had only been studied in the Brazilian population in this research, whether the phenomenon occurred in other people is 
unknown [43]. In addition, X chromosome abnormally seems significantly associated with age at onset of SCZ, particularly for the late onset. The frequency of the Turner's syndrome (2/38,5.3\%) and 47,XXX (1/38,2.6\%) in childhood onset $\mathrm{SCZ}$ are higher than the frequency of the Turner's syndrome $(11 / 6483,0.17 \%)$ [29] and 47,XXX $(22 / 8837,0.25 \%)$ [37] in adult onset SCZ, respectively [44]. In comparison with $\mathrm{X}$ chromosome aneuploidies, the abnormal passage of $\mathrm{Y}$ chromosome in SCZ is less reported, such as few case reports on males with XYY and XXYY. For example, one case of a 19-year-old white male with 47XYY karyotype was diagnosed SCZ by DSM-IV with aggressive behavior [45]. Another case found a 41-year-old caucasian man with 47XXYY karyotype who diagnosed in SCZ also showed impulsive aggression [46]. The reason for less Y chromosome aneuploidies reported in schizophrenia is related to the less commonality of extra copy of $\mathrm{Y}$ chromosome than the XXY or the XXX syndromes in general. In summary, it remains controversial as to whether sex chromosome abnormally, such as aneuploidies affect clinical symptoms of SCZ patients.

\section{Autism spectrum disorder (ASD)}

ASD is a developmental disorder which is 4-5 times more common among boys than girls. While the biological mechanisms of the sex bias remain unclear, genetic studies showed that sex chromosomes genetic mutation is clearly associated with ASD. For example, mutation of X-linked genes, such as $N L G N 3$ and $N L G N 4 X$, have been associated with ASD phenotype as described previously [15-17]. It is also observed that kids with $\mathrm{X}$ chromosome abnormalities often have problems in social behavioral [47], social cognition [48] and increase levels of ASD traits [49], a typical symptom of ASD. For the $\mathrm{X}$ chromosome aneuploidies with extra copies, a study identified 14 ASD patients from total of 51 boys with Klinefelter syndrome (XXY) (27\%) by ADI-R (the Autism Diagnostic Interview) [50], suggesting a possibility of extra copy of $X$ chromosome may add more risk for ASD. Another study of children with an extra copy of X chromosome $(n=$ $60)$, children with ASD $(n=58)$, or control kids $(n=106)$ found that kids (regardless boys or girls) with the extra copy of X chromosome expressed higher levels of social dysfunction and ASD symptoms than ASD and controls, particularly with increased social anxiety [47]. In addition, inactive $\mathrm{X}$ chromosome is also associated with ASD, such as Fragile $\mathrm{X}$, a disease caused by a single mutated gene (FMR1 protein, FMRP) on $\mathrm{X}$ chromosome. For example, a study of 120 children ( 80 boys and 40 girls) with the fragile $\mathrm{X}$ and their unaffected siblings showed $30 \%$ of children with fragile $X$ syndrome also has ASD [51]. Together, data suggest that both $X$ chromosome aneuploidies and impairment of $\mathrm{X}$ chromosome activity can increase risk of ASD. Compared to X chromosome, the Y chromosome abnormalities are often less studied due to its complex and repetitive DNA sequence structure, which makes hard to detect using conventional genetic technologies. Nevertheless, several early studies showed that child carries XYY developed infantile ASD [5254]. A study of 95 subjects with XXYY (age 1-55 years) demonstrated $92 \%$ language delay, $72 \%$ with ADHD, $28 \%$ with ASD, 47\% with mood disorders in the individuals with XXYY [55]. A recent systematic review also showed the association between ASD and XYY syndrome and a description of two new cases with this association [56]. These reports suggested that additional genetic mutations in $\mathrm{Y}$ chromosome might be also involved in ASD.

\section{Attention deficit hyperactivity disorder (ADHD)}

ADHD is other highly heterogeneous mental disorder. The incidence of ADHD in individuals with sex chromosome abnormality is higher than that in general population. There is a comprehensive study of sex chromosome aneuploidy in ADHD which included total of 167 participants with XXY $(n=56), \mathrm{XXX}(n=$ $25), \mathrm{XYY}(n=33)$ and XXYY $(n=53)$, respectively. The results showed that 96 out of 167 (58\%) individuals met DSM-IV criteria for ADHD, including 11 out of 56 (36 $\%$ ) individuals with XXY, 13 out of $25(52 \%)$ in XXX, 25 out of $33(76 \%)$ in XYY and 38 out of $53(72 \%)$ in XXYY [57]. Another study reported an 18-fold increase in the prevalence of ADHD in girls with Turner's Syndrome, and 4.8-fold increase in the risk of ADHD in combined boys and girls compared to the general population controls [58]. In addition to chromosome aneuploidies, a clinical case report found a 6 years old boy with ADHD carries a major de-novo Y chromosome abnormality, a deletion of the long arm and duplication of the short arm [59]. Together, while prevalence rates for ADHD in males and females is $2: 1$ in a general population, the sex differences in ADHD are increased significantly in the individuals carries sex chromosome aneuploidies as described [45].

\section{Mood disorders}

Compare with other psychiatric disorder, the sex chromosome abnormality in mood disorders has been less investigated. It is known that females are more vulnerable to mood disorders in general. Although some case reports found the sex chromosome aneuploidies in BPD such as $\mathrm{XXYY}$ and XXX, none had evidence for aneuploidies increasing risk of BPD [60-62]. A study investigated the aneuploidies of sex chromosomes and risk of BPD in 1122 individuals with sex chromosome aneuploidy and showed a lower incidence of BPD in subjects with Turner's syndrome and a higher BPD incidence in people carry 47, XYY. [41] The abnormalities of sex chromosome structure are also observed in a man with bipolar who has 
Table 2: Chromosomal rearrangements or anomalies associate with psychiatric disorder

\begin{tabular}{|c|c|c|c|}
\hline $\begin{array}{l}\text { Psychiatric } \\
\text { diagnosis }\end{array}$ & \begin{tabular}{|l|l|}
$\begin{array}{l}\text { Sex chromosome } \\
\text { abnormality }\end{array}$ \\
\end{tabular} & Comments & study \\
\hline \multirow[t]{9}{*}{$\mathrm{SCZ}$} & XYY & Case report, a 19-year-old white male with 47XYY karyotype diagnosed SCZ. & $1998[45]$ \\
\hline & XXYY & $\begin{array}{l}\text { Case report, a } 41 \text {-year-old Caucasian man with } 48 X X Y Y \text { karyotype who } \\
\text { diagnosed in SCZ with impulsive aggression. }\end{array}$ & $1996[46]$ \\
\hline & $45 \mathrm{X}$ & $45 \mathrm{X}$ carriers showed 3 times more frequent in SCZ than general populations. & $2000[38]$ \\
\hline & $45 \mathrm{X} / 46 \mathrm{XX}$ & Case report, a 21-year-old female with TS diagnosed by DSM-IV. & $2014[39]$ \\
\hline & $45 \mathrm{X} / 46 \mathrm{XX}$ & Case report, a 41- year-old female with TS diagnosed by DSM-IV. & $2010[40]$ \\
\hline & $45 \mathrm{X} / \mathrm{XX}, 47 \mathrm{XXX}$ & $\begin{array}{l}9 / 29 \text { female SCZ showed X chromosome aneuploidy, chromosome X loss in } \\
\text { the } 40 \text { s year group was significantly higher in SCZ than in age-matched normal } \\
\text { females. }\end{array}$ & $2010[43]$ \\
\hline & TS and 47XXX & TS $(2 / 38)$ and $47 \mathrm{XXX}(1 / 38)$ in SCZ onset at childhood. & $2008[44]$ \\
\hline & $46 \mathrm{XX} / 47 \mathrm{XXX} / 48 \mathrm{XXXX}$ & $\begin{array}{l}\text { A SCZ female with } 46 \mathrm{XX} / 47 \mathrm{XXX} / 48 \mathrm{XXXX} \text { and } 46 \mathrm{XX} / 45 \mathrm{Xkaryotype} \text { in her } \\
\text { mother. }\end{array}$ & $2010[35]$ \\
\hline & $\mathrm{XY} / \mathrm{XXY}, \mathrm{XYY}, \mathrm{XO}, \mathrm{XXX}$ & $\begin{array}{l}\text { XXY and XXX increase risk of SCZ. In } 7519 \text { SCZ patients, } 41 \text { carry XXY } \\
(0.54 \%), 21 \text { carry XYY }(0.28 \%) \text {. In } 8837 \text { SCZ, } 56 \text { carry XXX }(0.63 \%) \text {. } \\
\end{array}$ & $1994[37]$ \\
\hline \multirow[t]{9}{*}{ ASD } & $\mathrm{XXY}$ & 14 of $51 \mathrm{XXY}$ patients had diagnosis ASD by ASI-R. & $2009[50]$ \\
\hline & $\mathrm{XXY}$ & Case report, a16-year-old Caucasian male is diagnosed with ASD. & $2007[47]$ \\
\hline & XYY & A boy with $47 \mathrm{XXY}$ is diagnosed with ASD. & $1998[53]$ \\
\hline & XYY & A case report, a 7-year-old boy with XYY is diagnosed ASD. & $2009[54]$ \\
\hline & XYY & A case report, a four-year-old boy with $47 \mathrm{XXY}$ is diagnosed ASD. & $1984[52]$ \\
\hline & XYY & $\begin{array}{l}\text { It is reviewed the publications found } 42 \text { ASD in } 235 \text { XYY, and reported two } \\
\text { cases: a three-and-a-half-year-old male and two-and-a-half-year-old male both } \\
\text { have ASD with } 47 \mathrm{XYY} \text {. }\end{array}$ & $2014[56]$ \\
\hline & XXYY & $\begin{array}{l}95 \text { males with XXYY: ADHD (72.2\%), autism spectrum disorders }(28.3 \%) \text {, } \\
\text { mood disorders }(46.8 \%) \text {. }\end{array}$ & $2008[55]$ \\
\hline & $\mathrm{XCI}$ & $\begin{array}{l}\text { No major X-linked locus is likely to be involved in these ASD families with } \\
\text { skewed XCI in } 621 \text { mothers and } 182 \text { ASD girls. }\end{array}$ & $2008[76]$ \\
\hline & $\mathrm{XCI}$ & $\begin{array}{l}\text { By analyzing } 30 \text { ASD females and } 35 \text { female controls, increased X chromosome } \\
\text { skewness (e.g., }>80: 20 \%) \text { was detected in autism group }(33 \%) \text { compared to } \\
\text { controls (11\%); but no mutation of XIST gene was found in both groups. }\end{array}$ & $2005[77]$ \\
\hline \multirow[t]{3}{*}{ ADHD } & $\mathrm{XXY}, \mathrm{XXX}, \mathrm{XYY}$ & Higher risk of ADHD: XYY males $>$ XXY males $>$ XXX females. & $2012[57]$ \\
\hline & $\mathrm{XO}$ & $\begin{array}{l}\text { 18-fold increase in the prevalence of ADHD in girls with TS }(24 \%) \text { compared } \\
\text { with girls in the general population }(1.3 \%) \text { and a } 4.8 \text { fold increase when compared } \\
\text { with boys and girls in the general population }(5 \%) \text {. }\end{array}$ & $2006[58]$ \\
\hline & Fragment of Y & $\begin{array}{l}\text { Case report, an 8-year-old male have ADHD with deletion of the long arm and } \\
\text { duplication of the short arm in Y chromosome. }\end{array}$ & $2008[59]$ \\
\hline \multirow[t]{5}{*}{ BPD } & $\mathrm{XXY}$ & A case report, a BPD patient with Klinefelter's syndrome. & $1997[64]$ \\
\hline & XXYY & A case report, A man with $48 \mathrm{XXYY}$ syndrome is diagnosed BPD. & $2005[65]$ \\
\hline & XXYY, XXX & A review, it is reported 3 cases with $47 \mathrm{XXX}$ and 2 cases with $48 \mathrm{XXYY}$. & 1994[63] \\
\hline & Missing Y & $\begin{array}{l}\text { Case report, a } 25 \text {-year-old male with a deletion of the long arm of Y chromosome } \\
\text { is diagnosed BPD. }\end{array}$ & $2005[66]$ \\
\hline & Ring Y chromosome & Case report, a 31-year-old man carrying a ring $\mathrm{Y}$ chromosome is diagnosed BPD. & 2007[68] \\
\hline MDD & $45 \mathrm{X}, 47 \mathrm{XXY}$ & $\begin{array}{l}\text { It is found } 45 \mathrm{X} \text { and } 47 \mathrm{XXY} \text { by analyzing blood and Skin fibroblast samples from } \\
\text { a BPD patient and his parents. }\end{array}$ & $2012[60]$ \\
\hline RDD & $\mathrm{XO}$ & $\begin{array}{l}\text { The frequency of Turner's syndrome in } 2194 \text { RDD females }(0.14 \%) \text { is higher } \\
\text { than the frequency observed } 17017 \text { live-born infants }(0.018 \%) \text {. }\end{array}$ & $2016[61]$ \\
\hline SCZ, BPD & $\mathrm{XY} / \mathrm{XXY}, \mathrm{XYY}, \mathrm{XO}, \mathrm{XXX}$ & $\begin{array}{l}1122 \text { subjects with sex chromosome aneuploidy }(45 \mathrm{X} n=313 ; 47 \mathrm{XXX} \mathrm{n}=5 \text {; } \\
47 \mathrm{XXY} \mathrm{n}=641 ; 47 \mathrm{XYY} \mathrm{n}=111) \text {. No subjects with } 45 \mathrm{X} \text { or } 47 \mathrm{XXX} \text { are } \mathrm{SCZ} \text { or } \\
\mathrm{BPD}, 13 \mathrm{XXY} \text { and } 5 \mathrm{XYY} \text { are SCZ, } 7 \mathrm{XXY} \text { and } 2 \mathrm{XYY} \text { subjects are BPD. }\end{array}$ & $2001[41]$ \\
\hline MDD, BPD & $\mathrm{XCI}$ & $\begin{array}{l}X I S T \text { gene expression is higher in } 36 \text { female BPD compare to } 38 \text { MDD (14 males } \\
\text { and } 24 \text { females) and } 36 \text { healthy female controls. }\end{array}$ & $2015[67]$ \\
\hline
\end{tabular}

Notable: TS= Turner's Syndrome, XCI $=$ X Chromosome Inactive 
a deletion of the long arm of Y chromosome was identified in a karyotype analysis [63] and a man carries a ring $\mathrm{Y}$ chromosome [64]. Other studies of recurrent depressive disorder found higher frequency of Turner's syndrome in depressive patients than that in regular population $[65,66]$. While aneuploidy often expresses a notable phenotype caused by imbalance of gene dosage, one study of a family with two BPD patients (father and son) and one healthy member (mother) showed that the healthy mother carries more aneuploidic changes $(51 \%)$ than the father (25\%) and the son (7-11\%) in the skin fibroblasts [67]. One related explanation for the unmatched phenotype with aneuploidies is the dynamic changes of $\mathrm{x}$-linked escaping genes. A recent study of human lymphoblastoid cells showed that some X-linked escapee genes may be a common mechanism for development of psychiatric disorders between the patients with rare genetic diseases (XXY or XXX) and the general population of female with psychiatric disorders, including BPD [68].

\section{SEX CHROMOSOME INACTIVE HYPOTHESIS}

While females (XX) carry twice as many X-linked genes on their sex chromosomes as males (XY), one $\mathrm{X}$ chromosome in females is active, and the other is inactivated in order to keep the sex chromosome dosage balance between males and females. The $\mathrm{X}$ chromosome inactivation (XCI) occurs randomly which is initiated by Xist gene [69] and regulated by Tsix gene [70] as well as Ftx gene [71] as a part of $\mathrm{X}$ chromosome inactive centre. However, XCI can also be non-random or skewed which is usually defined by at least $80 \%$ preferential inactivation of X chromosomes. The skewed XCI plays a role in the incidence and presentation of diseases in females, such as Rett syndrome, X-linked intellectual disability and X-linked adrenoleukodystrophy [72]. Recently, studies discovered a major role for XCI in generating female-specific, genetically directed stochastic diversity on spatial scales in mammals which might affect CNS function via regulating neuronal development within and between individuals [73]. It is hypothesized that the instability of XCI predisposes to psychosis [74] and autoimmune disease [75]. Although most of psychiatric diseases, such as ADHD, ASD, SCZ are closely related to early neuronal development, whether XCI abnormality is related to psychiatric is underinvestigated. One study found no major X-linked gene subject to XCI conferring susceptibility to 621 mothers who has an ASD children and 182 affected girls [76], while others found XCI skewness may be related with ASD by comparing 30 females ASD to 35 age- and sex-matched controls, and found higher frequency of increased XCI skewness in ASD [77]. There is one study investigated the XCI in mood disorders. They found that the genes for Xist, which initiation of XCI and escaping are significantly altered in the lymphoblastoid cells of female patients with BPD or MDD [68], suggesting an impairment of $X$ chromosome function is involved in the mood disorders as showed in Table 2.

\section{CONCLUSIONS}

Sex differences in onset, clinical symptoms, prevalence as well as response to treatments in various psychiatric disorders have been well recognized. However, the underlying mechanisms remain unknown. In this review, we gathered the literatures and recent discoveries on sex chromosomal aberrations in SCZ, ASD, ADHD and major mood disorders, and highlighted the potential linkages between sex chromosome abnormalities and the psychiatric diseases. It offers a new insight to understand sex-specific pathogenesis of psychiatric disease. However, due to the limited numbers of studies on sex chromosome abnormalities in psychiatric disorders, there is still lacking of clear clue on the relationship between the sex chromosome and psychosis due to small sample size and inaccurate or insensitive methods of sex chromatin screening. In addition, there is a big gap between psychiatric patients with family history with mental disorder and sex chromosome aneuploidies. Therefore, future study full karyotyping of individuals with psychotic diseases, particularly with a strong family history of mental disorder is needed. Using the new powerful cytogenetic techniques, we may advance our search for sex specific aetiology of psychiatric illness

\section{CONFLICTS OF INTEREST}

There is no conflict of interest.

\section{REFERENCES}

1. Tartaglia NR, Ayari N, Hutaff-Lee C, Boada R. Attentiondeficit hyperactivity disorder symptoms in children and adolescents with sex chromosome aneuploidy: XXY, XXX, XYY, and XXYY. J Dev Behav Pediatr. 2012;33:309-318.

2. Van Rijn S, Swaab H. Executive dysfunction and the relation with behavioral problems in children with 47,XXY and 47,XXX. Genes Brain Behav. 2015;14:200-208.

3. Gao Q, Liu L, Li HM, Tang YL, Wu ZM, Chen Y, Wang YF, Qian QJ. Interactions between MAOA and SYP polymorphisms were associated with symptoms of attention-deficit/hyperactivity disorder in Chinese Han subjects. Am J Med Genet B Neuropsychiatr Genet. 2015;168B:45-53.

4. Ryan J, Carriere I, Ritchie K, Ancelin ML. Involvement of GPR50 polymorphisms in depression: independent replication in a prospective elderly cohort. Brain Behav.2015;5:e00313. 
5. Piton A, Gauthier J, Hamdan FF, Lafrenière RG, Yang Y, Henrion E, Laurent S, Noreau A, Thibodeau P, Karemera L, Spiegelman D, Kuku F, Duguay J, et al. Systematic resequencing of $\mathrm{X}$-chromosome synaptic genes in autism spectrum disorder and schizophrenia. Mol Psychiatry. 2011;16:867-880.

6. Skuse D, Morris J, Lawrence K. The amygdala and development of the social brain. Ann N Y Acad Sci. 2003;1008:91-101.

7. Van Rijn S, Aleman A, Swaab H, Kahn RS. Neurobiology of emotion and high risk for schizophrenia: role of the amygdala and the X-chromosome. Neurosci Biobehav Rev. 2005;29:385-397.

8. Sandhu HK, Sarkar M, Turner BM, Wassink TH, Philibert RA. Polymorphism analysis of HOPA: a candidate gene for schizophrenia. Am J Med Genet B Neuropsychiatr Genet. 2003;123B:33-38.

9. Philibert RA, Bohle P, Secrest D, Deaderick J, Sandhu H, Crowe R, Black DW. The association of the HOPA(12bp) polymorphism with schizophrenia in the NIMH Genetics Initiative for Schizophrenia sample. Am J Med Genet B Neuropsychiatr Genet. 2007;144B:743-747.

10. Philibert RA, Sandhu HK, Hutton AM, Wang Z, Arndt S, Andreasen NC, Crowe R, Wassink TH. Population-based association analyses of the HOPA12bp polymorphism for schizophrenia and hypothyroidism. Am J Med Genet. 2001;105:130-134.

11. Spinks R, Sandhu HK, Andreasen NC, Philibert RA. Association of the HOPA12bp allele with a large $\mathrm{X}$-chromosome haplotype and positive symptom schizophrenia. Am J Med Genet B Neuropsychiatr Genet. 2004;127B:20-27.

12. Hung CC, Yeh JI, Fang JS, Chen CH. No association of a dodecamer duplication in the human opposite paired (HOPA) gene with mental retardation and schizophrenia in Chinese patients from Taiwan. Psychiatry Res. 2003;119:163-166.

13. Kirov G, Georgieva L, Nikolov I, Zammit S, Jones G, Poriazova N, Tolev T, Owen R, Jones S, Owen MJ. Association analysis of the HOPA12bp polymorphism in schizophrenia and manic depressive illness. Am J Med Genet B Neuropsychiatr Genet. 2003;118B:16-19.

14. Philibert RA, Winfield SL, Sandhu HK, Martin BM, Ginns EI. The structure and expression of the human neuroligin-3 gene. Gene. 2000;246:303-310.

15. Thomson P, Wray N, Thomson A, Dunbar DR, Grassie MA, Condie A, Walker MT, Smith DJ, Pulford DJ, Muir W, Blackwood DH, Porteous DJ. Sex-specific association between bipolar affective disorder in women and GPR50, an X-linked orphan $\mathrm{G}$ protein-coupled receptor. Mol Psychiatry. 2005;10:470-478.

16. Delavest M, Even C, Benjemaa N, Poirier MF, Jockers $\mathrm{R}$, Krebs MO. Association of the intronic rs2072621 polymorphism of the X-linked GPR50 gene with affective disorder with seasonal pattern. Eur Psychiatry. 2012;27:369-371.

17. Jamain $\mathrm{S}$, Quach $\mathrm{H}$, Betancur $\mathrm{C}$, Råstam $\mathrm{M}$, Colineaux $\mathrm{C}$, Gillberg IC, Soderstrom H, Giros B, Leboyer M, Gillberg $\mathrm{C}$, Bourgeron T. Mutations of the X-linked genes encoding neuroligins NLGN3 and NLGN4 are associated with autism. Nat Genet. 2003;34:27-29.

18. Volaki K, Pampanos A, Kitsiou-Tzeli S, Vrettou C, Oikonomakis V, Sofocleous C, Kanavakis E. Mutation screening in the Greek population and evaluation of NLGN3 and NLGN4X genes causal factors for autism. Psychiatr Genet.2013;23:198-203.

19. Wermter AK, Kamp-Becker I, Strauch K, Schulte-Körne $\mathrm{G}$, Remschmidt $\mathrm{H}$. No evidence for involvement of genetic variants in the X-linked neuroligin genes NLGN3 and NLGN4X in probands with autism spectrum disorder on high functioning level. Am J Med Genet B Neuropsychiatr Genet. 2008;147:535-537.

20. Bemben MA, Nguyen QA, Wang T, Li Y, Nicoll RA, Roche KW. Autism-associated mutation inhibits protein kinase C-mediated neuroligin-4X enhancement of excitatory synapses. Proc Natl Acad Sci U S A. 2015;112:2551-2556.

21. Liu L, Cheng J, Su Y, Ji N, Gao Q, Li H1, Yang L, Sun L, Qian Q, Wang Y. Deficiency of Sustained Attention in ADHD and Its Potential Genetic Contributor MAOA. J Atten Disord. 2015:1087054715574832.

22. Schulze TG, Müller DJ, Krauss H, Scherk H, Ohlraun $\mathrm{S}$, Syagailo YV, Windemuth C, Neidt H, Grässle M, Papassotiropoulos A, Heun R, Nöthen MM, Maier W, et al. Association between a functional polymorphism in the monoamine oxidase A gene promoter and major depressive disorder. Am J Med Genet. 2000;96:801-803.

23. Karmakar A, Maitra S, Chakraborti B, Verma D, Sinha S, Mohanakumar KP, Rajamma U, Mukhopadhyay K. Monoamine oxidase $\mathrm{B}$ gene variants associated with attention deficit hyperactivity disorder in the IndoCaucasoid population from West Bengal. BMC Genet. 2016;17:1.

24. Piton A, Gauthier J, Hamdan F, Yang Y, Henrion E, Laurent S, Noreau A, Thibodeau P Karemera L, Spiegelman D, Kuku F, Duguay J, Destroismaisons L, et al. Systematic resequencing of $\mathrm{X}$-chromosome synaptic genes in autism spectrum disorder and schizophrenia. Mol Psychiatry. 2011;16:867-880.

25. Zammit S, Jones G, Jones SJ, Norton N, Sanders RD, Milham C, McCarthy GM, Jones LA, Cardno AG, Gray M, Murphy KC, O’Donovan MC, Owen MJ. Polymorphisms in the MAOA, MAOB, and COMT genes and aggressive behavior in schizophrenia. Am J Med Genet B Neuropsychiatr Genet. 2004;128:19-20.

26. Bergen SE, Fanous AH, Walsh D, O’Neill FA, Kendler KS. Polymorphisms in SLC6A4, PAH, GABRB3, and MAOB and modification of psychotic disorder features. Schizophr Res. 2009;109:94-97. 
27. Wong EH, So H-C, Li M, Wang Q, Butler AW, Paul B, Wu HM, Hui TC, Choi SC, So MT, Garcia-Barcelo MM, McAlonan GM, Chen EY, et al. Common variants on Xq28 conferring risk of schizophrenia in Han Chinese. Schizophr Bull. 2014;40:777-786.

28. Carney RM, Wolpert CM, Ravan SA, Shahbazian M, Ashley-Koch A, Cuccaro ML, Vance JM, PericakVance MA. Identification of MeCP2 mutations in a series of females with autistic disorder. Pediatr Neurol.2003;28:205-211.

29. Vourc'h P, Bienvenu T, Beldjord C, Chelly J, Barthélémy $\mathrm{C}$, Müh JP, Andres C. No mutations in the coding region of the Rett syndrome gene MECP2 in 59 autistic patients. Eur J Hum Genet. 2001;9:556-558.

30. Saito T, Parsia S, Papolos DF, Lachman HM. Analysis of the pseudoautosomal X-linked gene SYBL1in bipolar affective disorder: Description of a new candidate allele for psychiatric disorders. Am J Med Genet. 2000;96:317-323.

31. Müller DJ, Schulze TG, Jahnes E, Cichon S, Krauss H, Kesper K, Held T, Maier W, Propping P, Nöthen MM, Rietschel M. Association between a polymorphism in the pseudoautosomal X-linked gene SYBL1 and bipolar affective disorder. Am J Med Genet. 2002;114:74-78.

32. Ross JL, Tartaglia N, Merry DE, Dalva M, Zinn AR. Behavioral phenotypes in males with XYY and possible role of increased NLGN4Y expression in autism features. Genes Brain Behav. 2015;14:137-144.

33. Kopsida E, Stergiakouli E, Lynn PM, Wilkinson LS, Davies W. The Role of the Y Chromosome in Brain Function. Open Neuroendocrinol J. 2009;2:20-30.

34. Skaletsky H, Kuroda-Kawaguchi T, Minx PJ, Cordum HS, Hillier L, Brown LG, Repping S, Pyntikova T, Ali J, Bieri T, Chinwalla A, Delehaunty A, Delehaunty K, et al. The male-specific region of the human $\mathrm{Y}$ chromosome is a mosaic of discrete sequence classes. Nature. 2003;423:825837.

35. Koç A, Yirmibeş Karaoğuz M, Coşar B, Ferda Perçin E, Sahin S, Baysak E, Açikyürek K. The importance of systematic genetic approach to familial schizophrenia cases and discussion of cryptic mosaic X chromosome aneuploidies in schizophrenia pathogenesis. Int J Psychiatry Clin Pract.2010;14:204-211.

36. Nielsen J, Wohlert M. Chromosome abnormalities found among 34910 newborn children: results from a 13year incidence study in Århus, Denmark. Hum Genet. 1991;87:81-83.

37. DeLisi LE, Friedrich U, Wahlstrom J, Boccio-Smith A, Forsman A, Eklund K, Crow TJ. Schizophrenia and sex chromosome anomalies. Schizophr Bull. 1994;20:495-505.

38. Prior TI, Chue PS, Tibbo P. Investigation of Turner syndrome in schizophrenia. Am J Med Genet. 2000;96:373378.

39. Jung SY, Park JW, Kim DH, Jun YH, Lee JS, Lee JE. Mosaic Turner syndrome associated with schizophrenia.
Ann Pediatr Endocrinol Metab. 2014;19:42-44.

40. Roser P, Kawohl W. Turner syndrome and schizophrenia: a further hint for the role of the X-chromosome in the pathogenesis of schizophrenic disorders. World J Biol Psychiatry. 2010;11:239-242.

41. Mors O, Mortensen P, Ewald H. No evidence of increased risk for schizophrenia or bipolar affective disorder in persons with aneuploidies of the sex chromosomes. Psychol Med.2001;31:425-430.

42. Stone JF, Sandberg AA. Sex chromosome aneuploidy and aging. Mutat Res. 1995;338:107-113.

43. de Moraes LS1, Khayat AS, de Lima PD, Lima EM, Pinto GR, Leal MF, de Arruda Cardoso Smith M, Burbano RR. Chromosome X Aneuploidy in Brazilian Schizophrenic Patients. in Vivo. 24: 281-286 (2010) 2010.

44. Eckstrand K, Addington AM, Stromberg T, Merriman B, Miller R, Gochman P, Long R, Dutra A, Chen Z, Meltzer $\mathrm{P}$, Nelson SF, Rapoport JL. Sex chromosome anomalies in childhood onset schizophrenia: an update. Mol Psychiatry. 2008;13:910.

45. Rajagopalan M, MacBeth R, Varma SL. XYY chromosome anomaly and schizophrenia. Am J Med Genet. 1998;81:6465.

46. Lee JW. An XXYY male with schizophrenia. Aust N Z J Psychiatry. 1996;30:553-556.

47. van Rijn S, Stockmann L, Borghgraef M, Bruining H, van Ravenswaaij-Arts C, Govaerts L, Hansson K, Swaab H. The social behavioral phenotype in boys and girls with an extra $\mathrm{X}$ chromosome (Klinefelter syndrome and Trisomy X): a comparison with autism spectrum disorder. J Autism Dev Disord. 2014;44:310-320.

48. van Rijn S, Stockmann L, van Buggenhout G, van Ravenswaaij-Arts C, Swaab H. Social cognition and underlying cognitive mechanisms in children with an extra X chromosome: a comparison with autism spectrum disorder. Genes Brain Behav. 2014;13:459-467.

49. Bruining H, De Sonneville L, Swaab H, de Jonge M, Kas M, van Engeland H, Vorstman J. Dissecting the clinical heterogeneity of autism spectrum disorders through defined genotypes. PLoS One 2010;5:e10887.

50. Bruining H, Swaab H, Kas M, van Engeland H. Psychiatric characteristics in a self-selected sample of boys with Klinefelter syndrome. Pediatrics. 2009;123:e865-870.

51. Hessl D, Dyer-Friedman J, Glaser B, Wisbeck J, Barajas RG, Taylor A, Reiss AL. The influence of environmental and genetic factors on behavior problems and autistic symptoms in boys and girls with fragile $\mathrm{X}$ syndrome. Pediatrics. 2001;108:e88-e88.

52. Gillberg C, Winnergard I, Wahlstrom J. The sex chromosomes - one key to autism? An XYY case of infantile autism. Appl Res Ment Retard. 1984;5:353-360.

53. Nicolson R, Bhalerao S, Sloman L. 47,XYY karyotypes and pervasive developmental disorders. Can J Psychiatry. 1998;43:619-622. 
54. Kuczynski E, Bertola DR, Castro CI, Koiffmann CP, Kim CA. Infantile autism and 47,XYY karyotype. Arq Neuropsiquiatr.2009;67:717-718.

55. Tartaglia N, Davis S, Hench A, Beauregard R, Reynolds A, Fenton L, Albrecht L, Ross J, Visootsak J, Hansen R, Hagerman R. A new look at XXYY syndrome: medical and psychological features. Am J Med Genet A.2008;146A:1509-1522.

56. Margari L, Lamanna AL, Craig F, Simone M, Gentile M. Autism spectrum disorders in XYY syndrome: two new cases and systematic review of the literature. Eur J Pediatr. 2014;173:277-283.

57. Tartaglia NR, Ayari N, Hutaff-Lee C, Boada R. Attentiondeficit hyperactivity disorder symptoms in children and adolescents with sex chromosome aneuploidy: XXY, XXX, XYY, and XXYYJ . Dev Behav Pediatr. 2012;33:30958.

58. Russell HF, Wallis D, Mazzocco MM, Moshang T, Zackai E, Zinn AR, Ross JL, Muenke M. Increased prevalence of ADHD in Turner syndrome with no evidence of imprinting effects. J Pediatr Psychol. 2006;31:945-955.

59. Mulligan A, Gill M, Fitzgerald M. A case of ADHD and a major Y chromosome abnormality. J Atten Disord.. 2008;12:103-105.

60. Craddock N, Owen M. Chromosomal aberrations and bipolar affective disorder. Br J Psychiatry.1994;164:507-512.

61. Bekaroglu M, Soylu C, Soylu N, Bilici M. Bipolar affective disorder associated with Klinefelter's syndrome - a case report. Isr J Psychiatry Relat Sci. 1997;34:308-310.

62. Lolak S, Dannemiller E, Andres F. 48,XXYY syndrome, mood disorder, and aggression. Am J Psychiatry. 2005; $162: 1384$

63. Olajossy M, Olajossy-Hilkesberger L, Tkaczuk-Włach J. Bipolar affective disorder in a male with a deletion of $\mathrm{Y}$ chromosome-a case report. Bipolar disorders. 2005; 7:298301.

64. Mouaffak F, Gallarda T, Baup N, Olié JP, Krebs MO. Gender identity disorders and bipolar disorder associated with the ring Y chromosome. Am J Psychiatry. 2007 Jul;164(7):1122-3.

65. Rucker JJ, Tansey KE, Rivera M, Pinto D, Cohen-Woods S, Uher R, Aitchison KJ, Craddock N, Owen MJ, Jones L, Jones I, Korszun A, Barnes MR. Phenotypic Association Analyses With Copy Number Variation in Recurrent Depressive Disorder. Biol Psychiatry. 2016;79:329-336.

66. Nielsen J, Wohlert M. Chromosome abnormalities found among 34,910 newborn children: results from a 13year incidence study in Arhus, Denmark. Hum Genet. 1991;87:81-83.

67. Demirhan O, Demirbek B, Tunc E, Uslu IN, Cetiner S, Serin A. Identification of chromosome abnormalities in screening of a family with manic depression and psoriasis: predisposition to aneuploidy. Asian J Psychiatr . 2012;5:169-174.
68. Ji B, Higa KK, Kelsoe JR, Zhou X. Over-expression of XIST, the Master Gene for X Chromosome Inactivation, in Females With Major Affective Disorders. EBioMedicine. 2015;2:907-916.

69. Weakley SM, Wang H, Yao Q, Chen C. Expression and function of a large non-coding RNA gene XIST in human cancer. World J Surg.2011;35:1751-1756.

70. Lee J, Davidow LS, Warshawsky D. Tsix, a gene antisense to Xist at the X-inactivation centre. Nat Genet. 1999;21:400-404.

71. Chureau C, Chantalat S, Romito A, Galvani A, Duret L, Avner P, Rougeulle C. Ftx is a non- coding RNA which affects Xist expression and chromatin structure within the X-inactivation center region. Hum Mol Genet. 2011 Feb 15;20(4):705-18.

72. Briggs SF, Reijo Pera RA. X chromosome inactivation: recent advances and a look forward. Curr Opin Genet Dev. 2014;28:78-82.

73. Wu H, Luo J, Yu H, Rattner A, Mo A, Wang Y, Smallwood PM, Erlanger B, Wheelan SJ, Nathans J. Cellular resolution maps of X chromosome inactivation: implications for neural development, function, and disease. Neuron. 2014;81:103119.

74. Fieremans N, Van Esch H, Holvoet M, Van Goethem G, Devriendt K, Rosello M, Mayo S, Martinez F, Jhangiani S, Muzny DM, Gibbs RA, Lupski JR, Vermeesch JR, et al. Identification of Intellectual Disability Genes in Female Patients with a Skewed X-Inactivation Pattern. Hum Mutat 2016;37:804-811.

75. Kanaan SB, Onat OE, Balandraud N, Martin GV, Nelson JL, Azzouz DF, Auger I, Arnoux F, Martin M, Roudier J, Ozcelik T, Lambert NC. Evaluation of X Chromosome Inactivation with Respect to HLA Genetic Susceptibility in Rheumatoid Arthritis and Systemic Sclerosis. PLoS One. 2016;11:e0158550.

76. Gong X, Bacchelli E, Blasi F, Toma C, Betancur C, Chaste P, Delorme R, Durand CM, Fauchereau F, Botros HG, Leboyer M, Mouren-Simeoni MC, Nygren G, et al. Analysis of $\mathrm{X}$ chromosome inactivation in autism spectrum disorders. Am J Med Genet B Neuropsychiatr Genet. 2008;147:830-835.

77. Talebizadeh Z, Bittel DC, Veatch OJ, Kibiryeva N, Butler MG. Brief report: non-random X chromosome inactivation in females with autism. J Autism Dev Disord. 2005;35:675681 